\title{
Platelet-Derived Microvesicles in Cardiovascular Diseases
}

\author{
Maria T. K. Zaldivia', James D. McFadyen ${ }^{1,2,3}$, Bock Lim ${ }^{1}$, Xiaowei Wang ${ }^{1,2}$ \\ and Karlheinz Peter ${ }^{1,2,4 *}$
}

'Atherothrombosis and Vascular Biology, Baker Heart and Diabetes Institute, Melbourne, VIC, Australia, ${ }^{2}$ Department of Medicine, Monash University, Melbourne, VIC, Australia, ${ }^{3}$ Department of Haematology, The Alfred Hospital, Melbourne, VIC, Australia, ${ }^{4}$ Heart Centre, The Alfred Hospital, Melbourne, VIC, Australia

OPEN ACCESS

Edited by:

Rory R. Koenen,

Maastricht University,

Netherlands

Reviewed by:

Adam Bruno Ceroi,

Ghent University, Belgium

Leonard C. Edelstein,

Thomas Jefferson University,

United States

*Correspondence:

Karlheinz Peter

karlheinz.peter@baker.edu.au

Specialty section:

This article was submitted

to Atherosclerosis and

Vascular Medicine,

a section of the journal

Frontiers in Cardiovascular

Medicine

Received: 03 August 2017

Accepted: 07 November 2017

Published: 21 November 2017

Citation:

Zaldivia MTK, McFadyen JD, Lim B,

Wang $X$ and Peter $K$ (2017)

Platelet-Derived Microvesicles in

Cardiovascular Diseases.

Front. Cardiovasc. Med. 4:74.

doi: 10.3389/fcvm.2017.00074
Microvesicles (MVs) circulating in the blood are small vesicles (100-1,000 nm in diameter) derived from membrane blebs of cells such as activated platelets, endothelial cells, and leukocytes. A growing body of evidence now supports the concept that platelet-derived microvesicles (PMVs), the most abundant MVs in the circulation, are important regulators of hemostasis, inflammation, and angiogenesis. Compared with healthy individuals, a large increase of circulating PMVs has been observed, particularly in patients with cardiovascular diseases. As observed in MVs from other parent cells, PMVs exert their biological effects in multiple ways, such as triggering various intercellular signaling cascades and by participating in transcellular communication by the transfer of their "cargo" of cytoplasmic components and surface receptors to other cell types. This review describes our current understanding of the potential role of PMVs in mediating hemostasis, inflammation, and angiogenesis and their consequences on the pathogenesis of cardiovascular diseases, such as atherosclerosis, myocardial infarction, and venous thrombosis. Furthermore, new developments of the therapeutic potential of PMVs for the treatment of cardiovascular diseases will be discussed.

\footnotetext{
Keywords: microvesicles, platelet-derived microvesicles, cardiovascular disease, therapeutic potential, hemostasis, inflammation, angiogenesis
}

\section{INTRODUCTION}

Extracellular vesicles (EVs) encompass a broad range of vesicles released from cells (1). EVs can be classified into different subsets according to their size, cellular origin, content or the mechanism leading to their formation (Table 1). Microvesicles (MVs) - also referred to as microparticlesare vesicles typically around $100-1,000 \mathrm{~nm}$ in size. By contrast, smaller vesicles $(30-100 \mathrm{~nm})$ are referred to as exosomes, while larger vesicles containing nuclear materials are referred to as apoptotic bodies. Although there is a general consensus in most studies that apoptotic bodies are particles $>1 \mu \mathrm{m}(2,3)$, there are several studies that describe apoptotic bodies to have a smaller size range of $0.5 \mu \mathrm{m}(4,5)$.

In the context of platelet biology, the plasma membrane fragments shed from activated platelets initially observed to possess procoagulant function were described as "platelet dust" by Wolf (17). Subsequent studies employing electron microscopy demonstrated the budding of vesicles from the platelet plasma membrane (18) thus confirming the cellular origin of the fragments detected by Wolf (17). In fact, $60-90 \%$ of EVs have been shown to be derived from platelets as indicated by positive CD41 staining (19). Since then, the role of EVs in the field of cardiovascular research has garnered a huge amount of interest due to their putative role in various pathological conditions. 
TABLE 1 | Characteristics of extracellular vesicles.

\begin{tabular}{|c|c|c|c|}
\hline & Exosome & Microvesicle & Apoptotic body \\
\hline Size & $\approx 20-100 \mathrm{~nm}$ & $\approx 0.1-1 \mu \mathrm{m}$ & $>1 \mu \mathrm{m}$ \\
\hline Origin & Multivesicular bodies, internal compartments & Plasma membrane & Cellular fragments \\
\hline Markers & $\begin{array}{l}\text { - Tetraspanins (CD63, CD9, and CD81) } \\
\text { - ALG-2-interacting protein X } \\
\text { - Tumor susceptibility gene } 101 \text { protein } \\
\text { - Heat shock } 70-k D a \text { proteins } \\
\text { - Major histocompatibility complex class I and class II }\end{array}$ & $\begin{array}{l}\text { - Phosphatidylserine (PS) } \\
\text { - Integrins } \\
\text { - Selectins } \\
\text { - CD40 ligands } \\
\text { - Other antigens of parental cell }\end{array}$ & $\begin{array}{l}\text { - Histones } \\
\text { - Fragmented DNA } \\
\text { - PS }\end{array}$ \\
\hline Reference & $-(6-9)$ & $-(9-14)$ & $-(9,15,16)$ \\
\hline
\end{tabular}

Elevated levels of platelet-derived microvesicles (PMVs) are observed in diabetes mellitus, sepsis, rheumatoid arthritis, vascular inflammation, and cardiovascular diseases (20-31). Indeed, the pathological events associated with these diseases activate platelets (32-35), which have been demonstrated to increase PMV release, while at the same time, a subpopulation of PMVs coming from agonist-activated platelets have been demonstrated to contribute to pathological events (36). Thus, PMVs may well be both, one of the causes and a consequence of the pathophysiology that drives various diseases.

This review will focus on our current understanding of PMVs in mediating hemostasis, inflammation, and angiogenesis, which are all factors contributing to the pathogenesis of cardiovascular diseases. Furthermore, the clinical relevance of PMVs will be discussed in the context of their therapeutic potential in the treatment of cardiovascular diseases.

\section{FORMATION AND CLEARANCE OF PMVs}

Platelet-derived microvesicle formation is complex, and the exact mechanisms involved in the generation of PMVs to date remains to be clearly defined. However, it has been demonstrated that the generation of PMVs can be triggered by various mechanisms: (1) via platelet activation by soluble agonists or (2) shear stress or (3) glycoprotein (GP) IIb/IIIa outside-in signaling. In the case of platelet activation in response to soluble agonist stimulation or in response to high shear stress in the vasculature (37-39), sustained elevation of intracellular calcium has been observed, which initiates the loss of lipid asymmetry of the plasma membrane and cytoskeletal reorganization, ultimately leading to PMV generation (Figure 1) (40). The exposure of negatively charged phospholipids, such as phosphatidylserine (PS), on the outer leaflet of the plasma membrane is regulated by the calcium-dependent scramblase transmembrane protein (TMEM16F) (41). Likewise, calpain, a calcium-dependent protease, is central to regulating cytoskeletal reorganization thus facilitating PMV shedding (42). By contrast, unstimulated platelets have been demonstrated to generate PMVs via GPIIb/ IIIa signaling, which destabilizes the actin cytoskeleton, resulting in shedding of PMVs in the absence of soluble agonist stimulation (43). Once generated, PMVs have generally been observed to have a relatively short lifespan with studies demonstrating PMVs to have half-lives of $30 \mathrm{~min}$ in mice (44), $10 \mathrm{~min}$ in rabbits (45), and approximately $5.5 \mathrm{~h}$ in apheresis-derived
PMVs (46). Active endocytosis has been demonstrated to be involved in the clearance of MVs (47) including those of PMVs (48). Indeed, several studies demonstrated the involvement of PS-dependent phagocytic processes in the clearance of PMVs in the circulation $(44,49-52)$. Several opsonins such as complement component C3b, $\beta 2$-glycoprotein-1, lactadherin, and developmental endothelial locus-1 facilitate this PS-dependent phagocytosis $(44,49-51,53)$. Upon engulfment of EVs by phagocytic cells such as macrophages and dendritic cells, liver X receptor (LXR) and peroxisome proliferator-activated receptor pathways are activated, which both are known to be induced by lipid derivatives (54). Indeed, the activation of the cholesterol derivative-sensitive pathway LXR by PMVs has been previously demonstrated in plasmacytoid dendritic cells (pDCs) (52), thereby highlighting the importance of lipid composition of EVs on the target cell responses after engulfment. The internalization of PMVs is not only essential for the clearance of PMVs but also ensures the delivery of the MV content into the target cell and thereby exerting their effector functions. Although studies have shown PS-dependent phagocytosis to be involved in the clearance of PMVs, other mechanisms are also involved in this process, which have previously been reviewed in detail by Mulcahy et al. (55).

\section{COMPOSITION OF PMVs}

From the humble origin of being just "platelet dust," it is now apparent that PMVs can mediate a diverse range of physiological responses. Their capacity to exert their biological role is attributed to their cell membrane composition and molecular cargo. The phospholipid composition of PMVs is a composite of the platelet plasma and granule membranes with high cholesterol content, also indicating an enrichment of lipid rafts (35). PMVs share many of the antigens as their parental cells that regulate cell adhesion, activation, and coagulation reactions (Figure 1) (10-13). These include various GPs, tissue factors (TF), selectins, and coagulation factors V and VIII (10-13). PMVs are packed with numerous biological molecules, which facilitate the transportation and delivery of bioactive mediators that can modulate the function of target cells. PMVs carry cytokines and chemokines such as interleukin (IL)-1 $\beta$, CXCL4, CXCL7, and CCL5 $(11,56)$. In addition, a vast amount of proteins, growth factors, and genetic material such as ribonucleic acid (RNA), messenger RNA, and microRNA can be packaged into PMVs $(12,57-60)$. Moreover, 


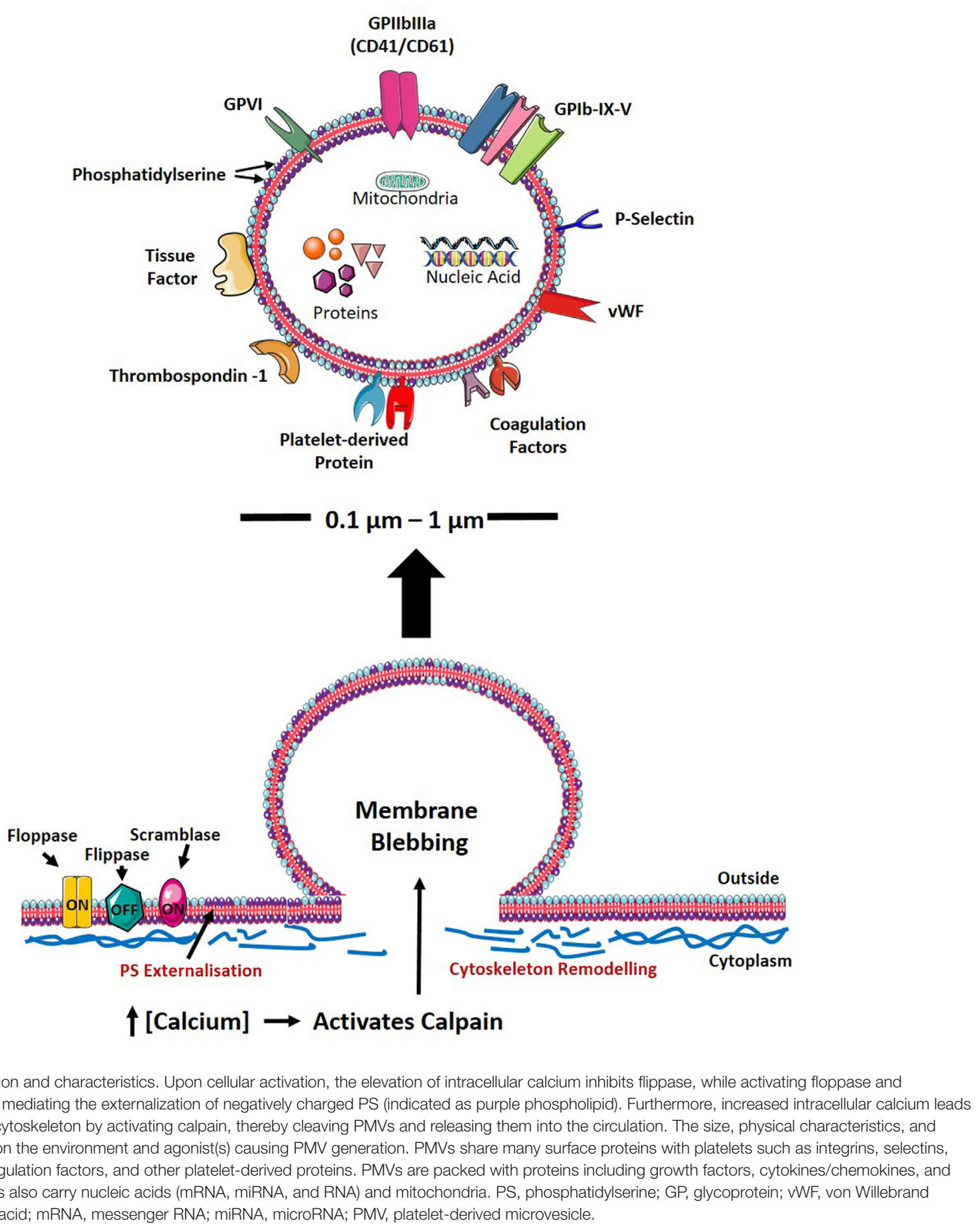

PMVs have recently been described to carry mitochondria, which can influence inflammatory responses (61).

The mechanisms of selective packaging have been demonstrated widely in EVs (62-65). Albeit not fully characterized in PMVs, the difference in lipid composition between PMVs and their parental cell, platelets (35), provide evidence for selective membrane assembly. Interestingly, it has been observed that the physical and biological components of PMVs are influenced by the stimulus used to generate PMVs (66-69). The heterogeneity observed in PMVs may explain why they have a diverse range of biological roles. For instance, larger PMVs may be enriched with more receptors and contents within, and thus can exert more effects, while smaller PMVs can deliver their biological cargo to areas that are otherwise difficult to enter, such as tumors, or to cross, such as the blood-brain barrier. Overall, it is important to understand that various pathological conditions will produce 
different types of PMVs carrying unique biological cargos that exert specific effects on targets cells. However, the precise mechanism by which PMVs selectively package and release their biological cargo to influence cellular function needs to be carefully determined in the future.

\section{BIOLOGICAL FUNCTION OF PMVs}

\section{Hemostasis}

It is perhaps not surprising that PMVs are most widely recognized for their role in mediating hemostasis given the resemblance in lipid composition and biological cargo they share with their parent cell-the platelet. Diseases that affect PMV shedding in the circulation have provided insight into their ability to regulate hemostasis. For example, patients with Castaman's defect, where platelets have an isolated inability to generate MVs display a bleeding phenotype (70). Similarly, Scott syndrome, where platelets cannot externalize PS and generate PMVs, is associated with a marked bleeding diathesis (41, 70-72). These disorders highlight the importance of PMVs in mediating hemostasis.

In accordance with their ability to regulate hemostasis, PMVs display both pro- and anticoagulant properties. The assembly of the tenase and prothrombinase complexes, and thus thrombin generation, is increased in the presence of PMVs due to the PS in the outer leaflet of the cell membrane (73). PMVs also express TF, which can initiate the extrinsic coagulation pathway by activating Factor VII $(73,74)$. On the contrary, PMVs have anticoagulant activity, which is associated with the binding of the natural anticoagulant, protein $\mathrm{S}$ and activation of protein $\mathrm{C}$ (75-79). Given the potential pro- and anticoagulant effects of PMVs, the tight regulation of PMV levels is likely an important factor regulating the hemostatic response.

\section{Inflammation}

Akin to the wealth of literature demonstrating an important pro-inflammatory role for platelets, there is now a growing body of evidence demonstrating that PMVs can regulate inflammatory responses. The immunoglobulins, antigens, cytokines, and chemokines that PMVs carry can directly regulate immune responses $(11,56,80)$. The pro-inflammatory effects of PMVs can be demonstrated through their interactions with monocytes and neutrophils. Mechanistically, PMVs bind to leukocytes and form aggregates and can induce monocytes to release inflammatory mediators including IL-1 $\beta$, tumor necrosis factor (TNF)- $\alpha$, monocyte chemoattractant protein-1, and matrix metalloproteinase (MMP)-9, which enhance monocyte migration $(81,82)$. Lipopolysaccharide-induced PMVs carry IL- $1 \beta$ in its mature form, which can activate endothelial cells and induce leukocyte adhesion thus promoting endothelial inflammation (56). Furthermore, mitochondria that are released in vivo in sterile inflammatory diseases, such as rheumatoid arthritis, have been observed to be packaged within PMVs, which can be hydrolyzed by phospholipase A2 IIA to generate bioactive mediators which promote neutrophil pro-inflammatory responses (61).
Intriguingly, there are reports that PMVs can also act as antiinflammatory mediators. Recently, Dinkla and colleagues (83) have shown that PMVs prevent the differentiation of regulatory T cells into a pro-inflammatory phenotype. PMVs can bind to CCR6-HLA-DR ${ }^{+}$regulatory $\mathrm{T}$ cell subsets via $\mathrm{P}$-selectin and inhibit the production of IL-17 and interferon- $\gamma$ (83). In accordance, $\mathrm{PMV}$ s from platelet concentrates can modify innate immune cells such as macrophages and dendritic cells. Macrophage activation is attenuated in the presence of PMVs as indicated by reduced production of TNF- $\alpha$ and IL-10 (84). PMVs also alter the function of monocyte-derived dendritic cells as demonstrated by their reduced capacity to present antigens, diminished production of pro-inflammatory cytokines and decreased phagocytic activity (84). PMVs can also modify inflammatory effects of the target cell. For instance, PMVs have been demonstrated to regulate the inflammatory responses of mast cells by the transfer of Lipoxygenase 12 (85). This leads to the production of Lipoxin A4, which induces anti-inflammatory and anti-angiogenic responses on endothelial cells by suppressing the generation of pro-inflammatory cytokines $(85,86)$. Furthermore, pDCs, a subset of dendritic cells that augment inflammatory processes by producing a large amount of pro-atherogenic type 1 interferons were observed to engulf PMVs in a PS-dependent manner (52). PMVs were observed to inhibit $\mathrm{pDCs}$ pro-inflammatory response by reducing the secretion of TNF- $\alpha$ and IL-8, signifying an antiinflammatory mechanism of PMVs (52).

In addition, our group has demonstrated that pentameric protein C-reactive protein (pCRP) binds to different MVs including PMVs (87). These pCRP-MVs, albeit not pro-inflammatory in healthy individuals, can aggravate existing tissue injury by activating the classical complement pathway and enhancing leukocyte recruitment to inflamed tissues (87). MVs not only bind pCRP but also convert pCRP to a highly pro-inflammatory monomer of C-reactive protein (mCRP), which can bind to endothelial cells and generate pro-inflammatory signals (88-91). In addition, autoantigen proteinase 3 , an elastin degrading protease, binds to PS expressing MVs, thereby promoting inflammation via the generation of reactive oxygen species in neutrophils (92). Thus, these studies further highlight the ability of PMVs to partner with proteins to induce a pro-inflammatory phenotype. Therefore, PMVs may play a dual role in inflammation as they may instigate either pro- or anti-inflammatory responses depending on the cell membrane composition and biological cargo transported by the PMV.

\section{Angiogenesis}

In addition to harboring a number of pro-inflammatory cytokines, PMVs may carry growth factors such as vascular endothelial growth factor (VEGF), fibroblast growth factor 2, and lipid growth factors suggesting PMVs may play an important role in regulating angiogenesis (93). In accordance, Kim and colleagues have demonstrated that PMVs can inhibit apoptosis while enhancing cell migration, proliferation, survival, and tube formation in human umbilical vein endothelial cells (93). PMVs may also enhance pro-angiogenic MMP-2 and MMP-9 expression in endothelial cells in vitro and in vivo (94). Furthermore, PMVs stimulate the growth of endothelial 
progenitor cells, thus contributing to the formation of new blood vessels (93).

The role of PMVs in regulating angiogenesis in the context of cardiovascular diseases has been highlighted by Brill and colleagues (95). The authors established that PMVs can induce angiogenesis in vitro caused by cytokines, VEGF, basic fibroblast growth factor, and platelet-derived growth factor packaged within PMVs in a process linked to Src, PI-3K, and ERK signaling (95). Moreover, the injection of PMVs in ischemic heart muscle induces the formation of blood vessels in a murine model of myocardial infarction (MI), signifying PMVs capability to induce myocardial angiogenesis in the setting of ischemia (95). PMVs have also been shown to facilitate endothelial repair after arterial injury by enhancing the vasoregenerative capacity of early outgrowth cells (EOCs) (96). PMVs enhance the recruitment, migration, and differentiation of EOCs at the site of injury by enhancing angiogenic growth factors that stimulate resident mature endothelial cells (96). The ability of PMVs to induce angiogenesis has also been demonstrated in the context of neurogenesis following brain injury and tumor progression $(97,98)$ thus, highlighting the potentially broad role of PMVs in endothelial repair and angiogenesis.

\section{PMVs IN CARDIOVASCULAR DISEASES}

\section{Atherosclerosis}

The rupturing of an atherosclerotic plaque can lead to MI and stroke, which are leading causes of death and disability globally. Indeed, excessive amounts of PMVs have been observed in patients with atherosclerosis (23-28). The increase in PMV numbers was found to correlate with multiple parameters including carotid artery intima media thickness, lipid-rich atherosclerotic plaques, and plaque burden (23-27). In the setting of atherosclerosis, increased hemodynamic shear stress due to plaque-associated luminal stenosis as well as the accumulation of oxidized low-density lipoprotein can activate platelets and stimulate generation of pro-inflammatory PMVs $(33,99)$. In atherosclerosis, monocytes adhere to activated endothelial cells, infiltrate the intima, and differentiate to tissue macrophages, which then engulf lipids and form foam cells (100). Smooth muscle cells migrate from the media to the intima and produce extracellular matrix, forming the fibrous cap (100). Macrophages and smooth muscle cells can undergo apoptosis leading to accumulation of extracellular lipid which forms the necrotic core (100). Indeed, PMVs have been implicated with these different stages of atherogenesis. For instance, PMVs encapsulate and transport miR-223 to endothelial cells, which can trigger endothelial apoptosis via the insulin-like growth factor-1 receptor (60). PMVs, together with endothelial MVs, increase endothelial permeability thereby influencing vascular endothelial dysfunction, an early step in the development of atherosclerosis (101). The presence of P-selectin expressed by PMVs allows them to interact with leukocytes via P-selectin GP ligand-1 thereby facilitating leukocyte accumulation at the site of endothelial injury and enhancing leukocyte infiltration from the blood vessel to the intima (82). Further to this,
PMVs can transfer the pro-atherogenic cytokine RANTES to endothelial cells and induce monocytes and endothelial cells to release pro-inflammatory cytokines such as IL-8, IL-1 $\beta$, TNF- $\alpha$, and IL-6, further enhancing leukocyte adhesion and infiltration (102-104). PMVs encapsulate active caspase- 3 that can induce macrophage apoptosis (105). As a consequence in atherosclerosis, lipids derived from dead macrophages can accumulate and can contribute to the formation of the necrotic core. Furthermore, PMVs have been demonstrated to stimulate smooth muscle cells, leading to the migration of smooth muscle from the media to the intima thereby enhancing lesion progression (106, 107).

However, the main caveat of these studies is the fact that PMVs are only detected in the circulating blood of patients with atherosclerosis but are not found in the atherosclerotic plaque itself (108). This raises the question as to whether PMVs are merely associated with atherogenesis or play an active role in disease pathogenesis. The absence of PMVs in the plaque, while intriguing because of the evidence of PMVs' infiltration in other inflamed tissues, such as arthritic joints (36), could suggest selective removal of PMVs as they engage with other cells and exert their effects at the intraluminal area of the vessel in the setting of atherosclerosis. PMVs are highly subjected to endocytosis/phagocytosis, due to the high expression of adhesion molecules and PS (109). This potentially enhances the clearance of PMVs in comparison with other blood streamderived MVs, which may possibly be one of the mechanisms contributing to the absence of PMVs in the atherosclerotic plaque. These are important questions for further studies.

\section{Acute Coronary Syndromes (ACS)}

High levels of circulatory PMVs have been observed in patients with ACS and are also associated with the degree of elevation of cardiac enzymes, IL-6, and CRP levels (29-31). The elevated levels of PMVs in the plasma of patients with ACS persisted for up to 4 years after MI and is linked with markers of coagulation activation and soluble CD40L (110). In accordance with these findings, PMVs have been demonstrated to correlate with the size of myocardium at risk and microvascular dysfunction after ST elevation MI (STEMI) (111, 112). Also, it appears likely that MVs play an active role in promoting vascular inflammation and cardiac damage in patients after an ACS since MVs, including PMVs containing pro-inflammatory isoforms of CRP, have been demonstrated to be elevated in these patients $(87,88)$. Furthermore, PMVs independently predict future admission for major bleeding in non-STEMI patients (113). Taken together, these data suggest that PMVs detected in patients with ACS may also act as reporters of vascular inflammation, microvascular obstruction and myocardial damage in cardiovascular diseases $(29,30,11$, 112). While elevated levels of PMVs are often observed in patients with ACS, there are few studies that have reported variances in the levels of PMVs and the lack of association of PMVs with the severity of coronary artery disease $(114,115)$. The discordance in the levels of PMVs in ACS may be due to the variability of inclusion criteria and medication of the patients enrolled in each study. Also, the lack of consensus in the characteristic and definition of MVs may account for the variations observed in the literature. 
Indeed, further studies are required, with establish common protocols and clear MVs nomenclature, to fully elucidate the role of PMVs in ACS.

\section{Thrombotic Disorders}

Thrombotic complications are often observed in patients with cardiovascular diseases. Augmented shedding of PMVs is deleterious and may contribute to thrombosis. For instance, in patients with immune thrombocytopenia, there are high levels of PMVs despite low platelet counts, which have been linked to a paradoxical increased risk of thrombotic events $(116,117)$. Increased PMVs are also detected in other thrombotic diseases such as acute pulmonary embolism and deep vein thrombosis (DVT) (118-121). Likewise, PMVs have been detected to be elevated in the context of thrombophilic states such antithrombin deficiency, protein $\mathrm{C}$ deficiency, and the Factor $\mathrm{V}$ Leiden mutation-all predispositions to venous thrombosis $(122,123)$. Increased levels of PMVs are observed to be associated with a heightened risk of venous thromboembolism, and PMVs have been proposed as a biomarker to help diagnose patients with DVT $(119,121)$. Similar to ACS, variation in plasma levels of PMVs are observed in thrombotic disorders (122, 124-126). Inconsistencies in processing blood samples such as handling, storage and methodology used in isolating PMVs may cause artifactual generation of PMVs and represent one of the underlying reasons for the discrepancies observed in the level of PMVs. Therefore, further studies are needed to fully unravel the role of PMVs in thrombotic diseases.

\section{CURRENT CHALLENGES IN EV RESEARCH}

Despite the remarkable progress in the field of EVs, clinical translation of EVs as a diagnostic or prognostic marker of pathological states remains a challenge (127). To fully unravel the potential of EVs in the diagnosis and therapy of cardiovascular diseases, it is imperative to understand the biological roles of PMVs in vivo. One of the drawbacks in the field of EVs is that most of the experiments demonstrating the physiological effects of EVs on target cells, such as endothelial cells, have been done in vitro in culture. The key weakness of this approach is that endothelial cells under in vivo conditions are under constant steady-state exposure to EVs. It is not clear how the response of cells in the in vitro, which is typically EV-free, to the sudden exposure of EVs is related to the in vivo setting. Furthermore, due to the lack of common practice in sample preparation and analysis, EV counts and phenotypes may vary dramatically between laboratories, making data analyses and clinical translation difficult. Indeed, several studies have highlighted the effects of pre-analytical variables on EV measurements. These include the type of anticoagulant used in collecting blood samples, centrifugation protocol, the storage of samples and staining protocols used for surface membrane antigens for determining the cellular origin of EVs (128-131). In regard to PMVs, preventing platelet activation and ensuring complete removal of platelets during processing of samples are crucial as this may result in inaccurate findings. It is also essential to be mindful of the storage and thawing conditions of samples as this leads to changes in the number of PMVs and Annexin V binding (128-130). In addition to this variability, sample handling, isolation protocol, different antigens used to determine cellular origin, inclusion criteria for patients, and their clinical characteristics may account for the qualitative and quantitative variations observed in the literature regarding the characterization of EVs.

The technological advancements have facilitated new methods to improve the purification and detection of EVs from biological fluids $(1,127,132-135)$. These include the following: sensitive single particle detection devices (tunable resistive pulse sensing; nanoparticle tracking analysis; and dynamic light scattering), flow cytometry (conventional; imaging; and impedance based), proteomics, and atomic force microscopy (1, 127, 130, 134, 136-138). However, a combination of multiple methods is still necessary to assess both physical and biological properties of EVs $(1,135)$. In light of the current limitation of EV studies, the International Society of Extracellular Vesicles endeavors to provide guidelines, harmonizing nomenclatures and practices in an effort to improve reproducibility of EV experiments and to eliminate ambiguity in the field of EVs (139-141). Furthermore, this society has already published several position papers in the Journal of Extracellular Vesicles (139-142) and provides public online databases that catalog EV-associated components, thereby assisting researchers to optimize their practices (EV-TRACK, ExoCarta, Vesiclepedia, and EVpedia).

\section{THERAPEUTIC POTENTIAL OF PMVs}

Given the role of PMVs in cardiovascular diseases, this raises the question as to whether MVs can be exploited for therapeutic benefit. Indeed, pharmacological studies that alter the levels of PMVs in the circulation have shown encouraging results (143-146). Also, the physical and biochemical properties of PMVs are advantages that can be utilized for the purpose of developing a therapy for cardiovascular diseases (Table 2). For

TABLE 2 | Advantages and disadvantages of extracellular vesicles (EVs) as emerging therapy for cardiovascular diseases.

\begin{tabular}{ll}
\hline Advantages & Disadvantages \\
\hline $\begin{array}{l}\text { Natural homing ability and specific } \\
\text { transfer of bioactive molecules } \\
(152,153)\end{array}$ & $\begin{array}{l}\text { Lack of standardization of pre-analytical } \\
\text { variables }(127,140)\end{array}$ \\
\hline $\begin{array}{l}\text { Highly hydrophobic drugs and } \\
\text { hydrophilic drugs can be packaged } \\
(152,154)\end{array}$ & $\begin{array}{l}\text { No clear nomenclature leading to variable } \\
\text { qualitative and quantitative analysis }(1,155)\end{array}$ \\
$\begin{array}{l}\text { Good delivery vehicle for drugs } \\
\text { based on the ability to cross blood- } \\
\text { brain barrier (153, 156) }\end{array}$ & $\begin{array}{l}\text { No recommended isolation protocol for } \\
\text { clinical grade production and quality control }\end{array}$ \\
\hline
\end{tabular}

Easy to adapt/optimize content and surface receptors for sitespecific delivery $(147,154,156)$ Comprised of heterogeneous components depending on the isolation, handling, and

More stable upon freezing and thawing compared with cells, biocompatible, and non-cytotoxic $(142,156)$ agonist(s) used (67, 69, 128-130)
The need to establish techniques and methodologies to rigorously quantify and characterized the molecular and physical aspects of EVs (142) 


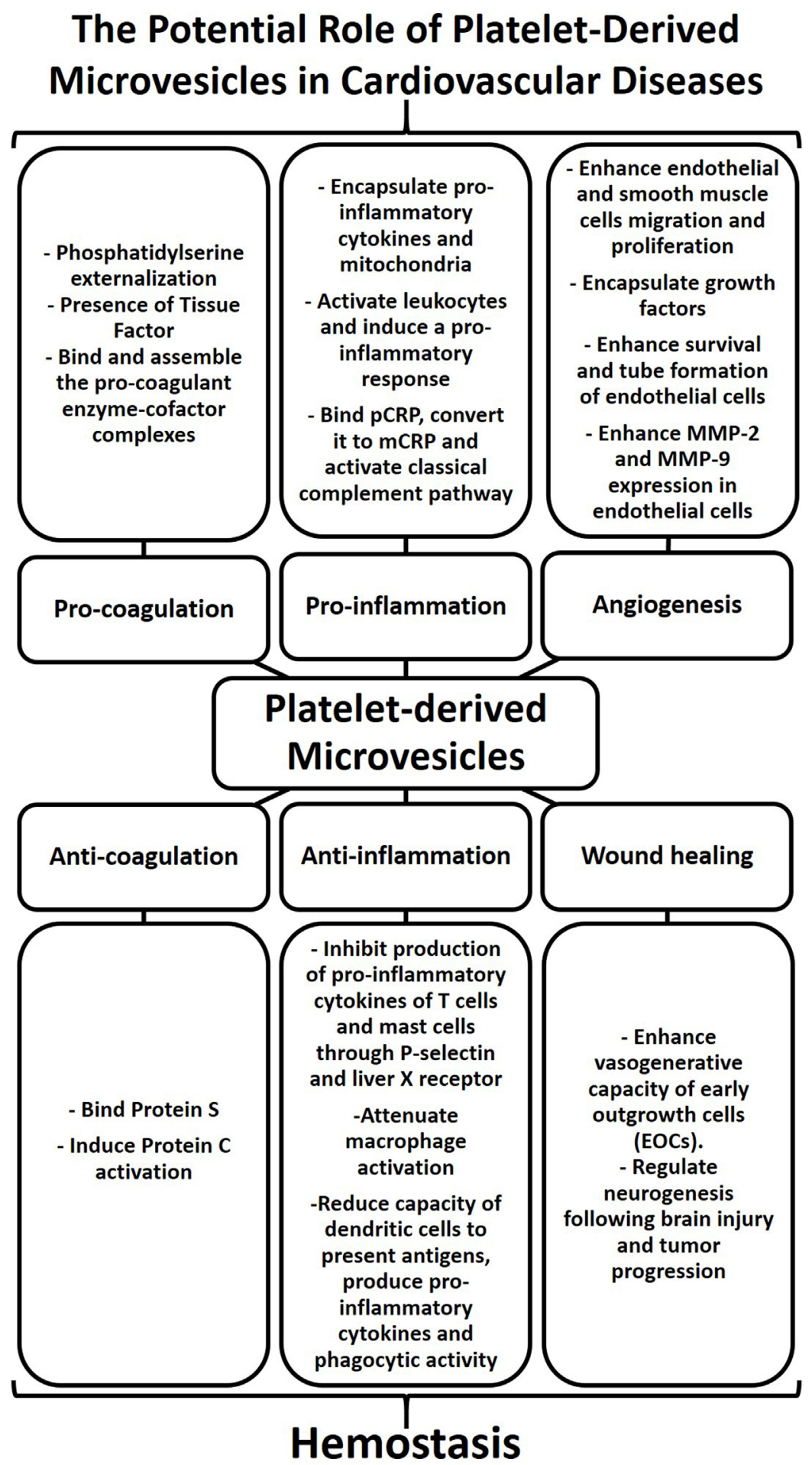

FIGURE 2 | Platelet-derived microvesicles (PMVs) as regulators of hemostasis and contributors to cardiovascular diseases. The physical characteristics of the cell membrane and biological cargo define the biological role of PMVs. PMVs bind natural anticoagulants thereby preventing coagulation. PMVs can also inhibit cytokine production leading to a reduction of vascular inflammation. In addition, PMVs can enhance the vasogenerative capacity of cells, thus highlighting their role in wound healing. While PMVs play a major role in regulating hemostasis, excessive numbers of PMVs can also contribute to cardiovascular diseases. The presence of phosphatidylserine and tissue factor in PMVs can induce procoagulant enzyme-cofactor complexes that favor thrombosis. PMVs can also induce cytokine production, bind protein C-reactive protein (pCRP), and convert it to monomer of C-reactive protein (mCRP), thereby promoting inflammatory responses. The activation of smooth muscle cells, endothelial cells, and leukocytes by PMVs as well as growth factors encapsulated within PMVs can stimulate angiogenesis. Therefore, PMVs may stimulate or dampen coagulation, inflammation, and angiogenesis and may thereby contribute to cardiovascular diseases. 
instance, PMV-inspired nanovesicles have been engineered to deliver thrombolysis specifically to sites of clot formation (147). The design of the therapeutic nano vesicle was based on the biological aspects of PMVs that are relevant to thrombus formation. Surface receptors GPIIb/IIIa and P-selectin were used to target the site of clot formation, and the enzyme phospholipase A2 was employed to rupture the vesicle and release the lytic drug, thus allowing the targeting of thrombolysis only at sites of clot formation (147). Thus, this study highlights the feasibility of altering the cargo of EVs and surface receptors for site-specific delivery (Table 2). Also, natural PMVs have showed therapeutic potential to treat cardiovascular diseases. Pretreating circulating-angiogenic cells (CACs) with PMVs derived from atherosclerotic patients (PMV-CACs) enhances the re-endothelization capacity of these cells (148). PMV-CACs enhance blood flow and increase capillary density in rats suffering from hind limb ischemia via PMV release of RANTES (148). Furthermore, a cardioprotective role of MVs, specifically PMVs, has been demonstrated in a study by Ma and colleagues (149). In this study, the transfusion of PMVs from rats that underwent hind limb ischemia-reperfusion preconditioning resulted in increased levels of PMVs and a reduction of infarct size, indicative of a protective role of PMVs in the context of cardiac ischemia-reperfusion injury. This was further supported by data showing that PMVs transfused into rats with middle cerebral artery occlusion reduced infarct area (150). Similarly, other types of EVs have shown promising therapeutic potential. EVs, mainly MVs and exosomes, displayed a cardioprotective role by enhancing the recovery of cardiac function in a postinfarct heart failure animal model (151). Although the precise mechanisms involved in the protective role of EVs in cardiovascular diseases is still incompletely understood, the capacity of EVs to carry vast biological cargos and their ability to transfer a wide array of bioactive molecules to target cells may explain the beneficial effect of EVs as a therapy for cardiovascular diseases. Furthermore, EVs can be used as a drug delivery system to increase solubility, stability, and bioavailability of hydrophobic drug in the blood circulation (Table 2). Sun et al. encapsulated the drug curcumin in exosomes and successfully delivered the drug to activated monocytes, thus inducing an anti-inflammatory response in a preclinical model of septic shock (152). Despite the early promise from these studies involving PMVs, further studies are needed to delineate the potential utility of PMVs in cardiovascular diseases. Further to this, a number of challenges remain in translating therapeutic EVs to the clinic (Table 2).

\section{REFERENCES}

1. van der Pol E, Böing AN, Gool EL, Nieuwland R. Recent developments in the nomenclature, presence, isolation, detection and clinical impact of extracellular vesicles. J Thromb Haemost (2016) 14(1):48-56. doi:10.1111/ jth. 13190

2. Boulanger CM, Loyer X, Rautou PE, Amabile N. Extracellular vesicles in coronary artery disease. Nat Rev Cardiol (2017) 14(5):259-72. doi:10.1038/ nrcardio. 2017.7

3. Aikawa E. Extracellular vesicles in cardiovascular disease: focus on vascular calcification. J Physiol (2016) 594(11):2877-80. doi:10.1113/JP272112

\section{CONCLUSION}

Platelet-derived microvesicles have indeed come a long way from their initial descriptions as "platelet dust" to now being considered as major mediators of intercellular communication. Their role in hemostasis, inflammation, angiogenesis, and wound healing may be beneficial or deleterious and can contribute to the pathogenesis of cardiovascular diseases (Figure 2). PMVs represent a heterogeneous population of EVs derived from platelets. This heterogenicity is mainly due to the variability of stimuli capable of inducing platelet activation and PMV release. Indeed, the mode of platelet activation seems to define the size, content, and amount of PMVs, which together dictate their fate (cell targeting or not) and their effects and potential involvement in diseases. However, despite the undoubted progress in our understanding of the biological roles PMVs, there remains a pressing need to establish common protocols, analysis, and nomenclature in the field of EV research. Advancing our knowledge of the biological function of EVs holds promise to influence the treatment of cardiovascular diseases. Most interestingly, EV-based therapy represents an emerging and novel biological therapeutic approach for cardiovascular diseases. Therefore, harnessing our knowledge of EV biology may indeed unlock the full potential of EVs for the diagnosis and therapy of cardiovascular diseases and beyond.

\section{AUTHOR CONTRIBUTIONS}

All authors listed have made a substantial, direct, and intellectual contribution to the work and approved it for publication.

\section{ACKNOWLEDGMENTS}

Figures were produced using Servier Medical Art.

\section{FUNDING}

This study was supported by the National Health and Medical Research Council of Australia (NHMRC). JM is supported by the Haematology Society of Australia and New Zealand (HSANZ) New Investigator Scholarship, XW is supported by the National Heart Foundation of Australia Postdoctoral Fellowship and the Baker Fellowship. KP is supported by an NHMRC Principal Research Fellowship.

4. Crescitelli R, Lässer C, Szabó TG, Kittel A, Eldh M, Dianzani I, et al. Distinct RNA profiles in subpopulations of extracellular vesicles: apoptotic bodies, microvesicles and exosomes. J Extracell Vesicles (2013) 2(1):20677. doi:10.3402/jev.v2i0.20677

5. Akers JC, Gonda D, Kim R, Carter BS, Chen CC. Biogenesis of extracellular vesicles (EV): exosomes, microvesicles, retrovirus-like vesicles, and apoptotic bodies. J Neurooncol (2013) 113(1):1-11. doi:10.1007/s11060-0131084-8

6. Willms E, Johansson HJ, Mäger I, Lee Y, Blomberg KE, Sadik M, et al. Cells release subpopulations of exosomes with distinct molecular and biological properties. Sci Rep (2016) 6:22519. doi:10.1038/srep22519 
7. Kowal J, Arras G, Colombo M, Jouve M, Morath JP, Primdal-Bengtson B, et al. Proteomic comparison defines novel markers to characterize heterogeneous populations of extracellular vesicle subtypes. Proc Natl Acad Sci U S A (2016) 113(8):8. doi:10.1073/pnas.1521230113

8. Poe AJ, Knowlton AA. Exosomes as agents of change in the cardiovascular system. J Mol Cell Cardiol (2017) 111:40-50. doi:10.1016/j.yjmcc.2017. 08.002

9. Thery C, Ostrowski M, Segura E. Membrane vesicles as conveyors of immune responses. Nat Rev Immunol (2009) 9(8):581-93. doi:10.1038/ nri2567

10. Müller I, Klocke A, Alex M, Kotzsch M, Luther T, Morgenstern E, et al. Intravascular tissue factor initiates coagulation via circulating microvesicles and platelets. FASEB J (2003) 17(3):476-8. doi:10.1096/fj.02-0574fje

11. Garcia BA, Smalley DM, Cho H, Shabanowitz J, Ley K, Hunt DF. The platelet microparticle proteome. J Proteome Res (2005) 4(5):1516-21. doi:10.1021/ pr0500760

12. Vélez P, Izquierdo I, Rosa I, García Á. A 2D-DIGE-based proteomic analysis reveals differences in the platelet releasate composition when comparing thrombin and collagen stimulations. Sci Rep (2015) 5:8198. doi:10.1038/ srep08198

13. Mobarrez F, Sjövik C, Soop A, Hållström L, Frostell C, Pisetsky DS, et al. CD40L expression in plasma of volunteers following LPS administration: a comparison between assay of $\mathrm{CD} 40 \mathrm{~L}$ on platelet microvesicles and soluble CD40L. Platelets (2015) 26(5):486-90. doi:10.3109/09537104. 2014.932339

14. Mause SF, Weber C. Microparticles: protagonists of a novel communication network for intercellular information exchange. Circ Res (2010) 107(9): 1047-57. doi:10.1161/CIRCRESAHA.110.226456

15. Hristov M, Erl W, Linder S, Weber PC. Apoptotic bodies from endothelial cells enhance the number and initiate the differentiation of human endothelial progenitor cells in vitro. Blood (2004) 104(9):2761-6. doi:10.1182/ blood-2003-10-3614

16. Kerr JF, Wyllie AH, Currie AR. Apoptosis: a basic biological phenomenon with wide-ranging implications in tissue kinetics. Br J Cancer (1972) 26(4):239-57. doi:10.1038/bjc.1972.33

17. Wolf $\mathrm{P}$. The nature and significance of platelet products in human plasma. Br J Haematol (1967) 13(3):269-88. doi:10.1111/j.1365-2141.1967.tb08741.x

18. Sandberg H, Bode AP, Dombrose FA, Hoechli M, Lentz BR. Expression of coagulant activity in human platelets: release of membranous vesicles providing platelet factor 1 and platelet factor 3. Thromb Res (1985) 39(1): 63-79. doi:10.1016/0049-3848(85)90122-7

19. Brisson AR, Tan S, Linares R, Gounou C, Arraud N. Extracellular vesicles from activated platelets: a semiquantitative cryo-electron microscopy and immuno-gold labeling study. Platelets (2017) 28(3):263-71. doi:10.1080/ 09537104.2016.1268255

20. Duchez AC, Boudreau LH, Naika GS, Bollinger J, Belleannée C, Cloutier N, et al. Platelet microparticles are internalized in neutrophils via the concerted activity of 12-lipoxygenase and secreted phospholipase A2-IIA. Proc Natl Acad Sci U S A (2015) 112(27):E3564-73. doi:10.1073/pnas. 1507905112

21. Zhang Y, Meng H, Ma R, He Z, Wu X, Cao M, et al. Circulating microparticles, blood cells, and endothelium induce procoagulant activity in sepsis through phosphatidyleserine exposure. Shock (2016) 45(3):299-307. doi:10.1097/ SHK.0000000000000509

22. Li S, Wei J, Zhang C, Li X, Meng W, Mo X, et al. Cell-derived microparticles in patients with type 2 diabetes mellitus: a systematic review and metaanalysis. Cell Physiol Biochem (2016) 39(6):2439-50. doi:10.1159/000452512

23. Fortin PR, Cloutier N, Bissonnette V, Aghdassi E, Eder L, Simonyan D, et al. Distinct subtypes of microparticle-containing immune complexes are associated with disease activity, damage, and carotid intima-media thickness in systemic lupus erythematosus. J Rheumatol (2016) 43(11):2019-25. doi:10.3899/jrheum. 160050

24. Suades R, Padró T, Alonso R, Mata P, Badimon L. High levels of TSP1+/ CD142+ platelet-derived microparticles characterise young patients with high cardiovascular risk and subclinical atherosclerosis. Thromb Haemost (2015) 114(6):1310-21. doi:10.1160/TH15-04-0325

25. Lukasik M, Rozalski M, Luzak B, Michalak M, Ambrosius W, Watala C, et al. Enhanced platelet-derived microparticle formation is associated with carotid atherosclerosis in convalescent stroke patients. Platelets (2013) 24(1):63-70. doi:10.3109/09537104.2011.654292

26. Csongrádi É, Nagy B Jr, Fulop T, Varga Z, Karányi Z, Magyar MT, et al. Increased levels of platelet activation markers are positively associated with carotid wall thickness and other atherosclerotic risk factors in obese patients. Thromb Haemost (2011) 106(4):683-92. doi:10.1160/TH1101-0030

27. Kuriyama N, Nagakane Y, Hosomi A, Ohara T, Kasai T, Harada S, et al. Evaluation of factors associated with elevated levels of platelet-derived microparticles in the acute phase of cerebral infarction. Clin Appl Thromb Hemost (2010) 16(1):26-32. doi:10.1177/1076029609338047

28. Tan KT, Tayebjee MH, Lim HS, Lip GY. Clinically apparent atherosclerotic disease in diabetes is associated with an increase in platelet microparticle levels. Diabet Med (2005) 22(12):1657-62. doi:10.1111/j.1464-5491.2005. 01707.x

29. Cui Y, Zheng L, Jiang M, Jia R, Zhang X, Quan Q, et al. Circulating microparticles in patients with coronary heart disease and its correlation with interleukin-6 and C-reactive protein. Mol Biol Rep (2013) 40(11):6437-42. doi:10.1007/s11033-013-2758-1

30. Stępień E, Stankiewicz E, Zalewski J, Godlewski J, Zmudka K, Wybrańska I. Number of microparticles generated during acute myocardial infarction and stable angina correlates with platelet activation. Arch Med Res (2012) 43(1):31-5. doi:10.1016/j.arcmed.2012.01.006

31. Hartopo AB, Puspitawati I, Gharini PP, Setianto BY. Platelet microparticle number is associated with the extent of myocardial damage in acute myocardial infarction. Arch Med Sci (2016) 12(3):529-37. doi:10.5114/ aoms.2016.59926

32. Webber AJ, Johnson SA. Platelet participation in blood coagulation aspects of hemostasis. Am J Pathol (1970) 60(1):19-42.

33. Holme PA, Orvim U, Hamers MJ, Solum NO, Brosstad FR, Barstad RM, et al. Shear-induced platelet activation and platelet microparticle formation at blood flow conditions as in arteries with a severe stenosis. Arterioscler Thromb Vasc Biol (1997) 17(4):646-53. doi:10.1161/01.ATV. 17.4.646

34. Sakariassen KS, Holme PA, Orvim U, Barstad RM, Solum NO, Brosstad FR. Shear-induced platelet activation and platelet microparticle formation in native human blood. Thromb Res (1998) 92(6 Suppl 2):S33-41. doi:10.1016/ S0049-3848(98)00158-3

35. Biró E, Akkerman JW, Hoek FJ, Gorter G, Pronk LM, Sturk A, et al. The phospholipid composition and cholesterol content of platelet-derived microparticles: a comparison with platelet membrane fractions. J Thromb Haemost (2005) 3(12):2754-63. doi:10.1111/j.1538-7836.2005.01646.x

36. Boilard E, Nigrovic PA, Larabee K, Watts GF, Coblyn JS, Weinblatt ME, et al. Platelets amplify inflammation in arthritis via collagen-dependent microparticle production. Science (2010) 327(5965):580-3. doi:10.1126/ science.1181928

37. Connor DE, Exner T, Ma DD, Joseph JE. The majority of circulating platelet-derived microparticles fail to bind annexin V, lack phospholipiddependent procoagulant activity and demonstrate greater expression of glycoprotein Ib. Thromb Haemost (2010) 103(5):1044-52. doi:10.1160/ TH09-09-0644

38. Diehl P, Aleker M, Helbing T, Sossong V, Germann M, Sorichter S, et al. Increased platelet, leukocyte and endothelial microparticles predict enhanced coagulation and vascular inflammation in pulmonary hypertension. J Thromb Thrombolysis (2011) 31(2):173-9. doi:10.1007/s11239-0100507-z

39. Diehl P, Nagy F, Sossong V, Helbing T, Beyersdorf F, Olschewski M, et al. Increased levels of circulating microparticles in patients with severe aortic valve stenosis. Thromb Haemost (2008) 99(4):711-9. doi:10.1160/ TH07-05-0334

40. Pasquet JM, Dachary-Prigent J, Nurden AT. Calcium influx is a determining factor of calpain activation and microparticle formation in platelets. Eur J Biochem (1996) 239(3):647-54. doi:10.1111/j.1432-1033.1996. 0647u.x

41. Fujii T, Sakata A, Nishimura S, Eto K, Nagata S. TMEM16F is required for phosphatidylserine exposure and microparticle release in activated mouse platelets. Proc Natl Acad Sci U S A (2015) 112(41):12800-5. doi:10.1073/ pnas. 1516594112 
42. Crespin M, Vidal C, Picard F, Lacombe C, Fontenay M. Activation of PAK1/2 during the shedding of platelet microvesicles. Blood Coagul Fibrinolysis (2009) 20(1):63-70. doi:10.1097/MBC.0b013e32831bc310

43. Cauwenberghs S, Feijge MA, Harper AG, Sage SO, Curvers J, Heemskerk JW. Shedding of procoagulant microparticles from unstimulated platelets by integrin-mediated destabilization of actin cytoskeleton. FEBS Lett (2006) 580(22):5313-20. doi:10.1016/j.febslet.2006.08.082

44. Flaumenhaft R. Formation and fate of platelet microparticles. Blood Cells Mol Dis (2006) 36(2):182-7. doi:10.1016/j.bcmd.2005.12.019

45. Rand ML, Wang H, Bang KW, Packham MA, Freedman J. Rapid clearance of procoagulant platelet-derived microparticles from the circulation of rabbits. J Thromb Haemost (2006) 4(7):1621-3. doi:10.1111/j.1538-7836.2006. 02011.x

46. Rank A, Nieuwland R, Crispin A, Grützner S, Iberer M, Toth B, et al. Clearance of platelet microparticles in vivo. Platelets (2011) 22(2):111-6. doi:10.3109/09537104.2010.520373

47. Angelot F, Seillès E, Biichlé S, Berda Y, Gaugler B, Plumas J, et al. Endothelial cell-derived microparticles induce plasmacytoid dendritic cell maturation: potential implications in inflammatory diseases. Haematologica (2009) 94(11):1502-12. doi:10.3324/haematol.2009.010934

48. Faille D, El-Assaad F, Mitchell AJ, Alessi MC, Chimini G, Fusai T, et al. Endocytosis and intracellular processing of platelet microparticles by brain endothelial cells. J Cell Mol Med (2012) 16(8):1731-8. doi:10.1111/j. 1582-4934.2011.01434.x

49. Dasgupta SK, Abdel-Monem H, Niravath P, Le A, Bellera RV, Langlois K, et al. Lactadherin and clearance of platelet-derived microvesicles. Blood (2009) 113(6):1332-9. doi:10.1182/blood-2008-07-167148

50. Abdel-Monem H, Dasgupta SK, Le A, Prakasam A, Thiagarajan P. Phagocytosis of platelet microvesicles and beta2- glycoprotein I. Thromb Haemost (2010) 104(2):335-41. doi:10.1160/TH09-12-0849

51. Dasgupta SK, Le A, Chavakis T, Rumbaut RE, Thiagarajan P. Developmental endothelial locus-1 (Del-1) mediates clearance of platelet microparticles by the endothelium. Circulation (2012) 125(13):1664-72. doi:10.1161/ CIRCULATIONAHA.111.068833

52. Ceroi A, Delettre FA, Marotel C, Gauthier T, Asgarova A, Biichlé S, et al. The anti-inflammatory effects of platelet-derived microparticles in human plasmacytoid dendritic cells involve liver X receptor activation. Haematologica (2016) 101(3):e72-6. doi:10.3324/haematol.2015.135459

53. Köppler B, Cohen C, Schlöndorff D, Mack M. Differential mechanisms of microparticle transfer to B cells and monocytes: anti-inflammatory properties of microparticles. Eur J Immunol (2006) 36(3):648-60. doi:10.1002/ eji.200535435

54. A-Gonzalez N, Hidalgo A. Nuclear receptors and clearance of apoptotic cells: stimulating the macrophage's appetite. Front Immunol (2014) 5:211. doi:10.3389/fimmu.2014.00211

55. Mulcahy LA, Pink RC, Carter DR. Routes and mechanisms of extracellular vesicle uptake. J Extracell Vesicles (2014) 3(1):24641. doi:10.3402/jev.v3. 24641

56. Lindemann S, Tolley ND, Dixon DA, McIntyre TM, Prescott SM, Zimmerman GA, et al. Activated platelets mediate inflammatory signaling by regulated interleukin 1beta synthesis. J Cell Biol (2001) 154(3):485-90. doi: $10.1083 /$ jcb. 200105058

57. Diehl P, Fricke A, Sander L, Stamm J, Bassler N, Htun N, et al. Microparticles: major transport vehicles for distinct microRNAs in circulation. Cardiovasc Res (2012) 93(4):633-44. doi:10.1093/cvr/cvs007

58. Liang H, Yan X, Pan Y, Wang Y, Wang N, Li L, et al. MicroRNA-223 delivered by platelet-derived microvesicles promotes lung cancer cell invasion via targeting tumor suppressor EPB41L3. Mol Cancer (2015) 14:58. doi:10.1186/ s12943-015-0327-z

59. Jansen F, Yang X, Proebsting S, Hoelscher M, Przybilla D, Baumann K, et al. MicroRNA expression in circulating microvesicles predicts cardiovascular events in patients with coronary artery disease. J Am Heart Assoc (2014) 3(6):e001249. doi:10.1161/JAHA.114.001249

60. Pan Y, Liang H, Liu H, LiD, Chen X, Li L, et al. Platelet-secreted microRNA-223 promotes endothelial cell apoptosis induced by advanced glycation end products via targeting the insulin-like growth factor 1 receptor. J Immunol (2014) 192(1):437-46. doi:10.4049/jimmunol.1301790

61. Boudreau LH, Duchez AC, Cloutier N, Soulet D, Martin N, Bollinger J, et al. Platelets release mitochondria serving as substrate for bactericidal group
IIA-secreted phospholipase A2 to promote inflammation. Blood (2014) 124(14):2173-83. doi:10.1182/blood-2014-05-573543

62. Iavello A, Frech VS, Gai C, Deregibus MC, Quesenberry PJ, Camussi G. Role of Alix in miRNA packaging during extracellular vesicle biogenesis. Int J Mol Med (2016) 37(4):958-66. doi:10.3892/ijmm.2016.2488

63. Janas T, Janas MM, Sapoń K, Janas T. Mechanisms of RNA loading into exosomes. FEBS Lett (2015) 589(13):1391-8. doi:10.1016/j.febslet.2015. 04.036

64. Zhang J, Li S, Li L, Li M, Guo C, Yao J, et al. Exosome and exosomal microRNA: trafficking, sorting, and function. Genomics Proteomics Bioinformatics (2015) 13(1):17-24. doi:10.1016/j.gpb.2015.02.001

65. Klein-Scory S, Tehrani MM, Eilert-Micus C, Adamczyk KA, Wojtalewicz N, Schnölzer M, et al. New insights in the composition of extracellular vesicles from pancreatic cancer cells: implications for biomarkers and functions. Proteome Sci (2014) 12(1):50. doi:10.1186/s12953-014-0050-5

66. Dean WL, Lee MJ, Cummins TD, Schultz DJ, Powell DW. Proteomic and functional characterisation of platelet microparticle size classes. Thromb Haemost (2009) 102(4):711-8. doi:10.1160/TH09-04-243

67. Milioli M, Ibáñez-Vea M, Sidoli S, Palmisano G, Careri M, Larsen MR. Quantitative proteomics analysis of platelet-derived microparticles reveals distinct protein signatures when stimulated by different physiological agonists. J Proteomics (2015) 121:56-66. doi:10.1016/j.jprot.2015.03.013

68. Shai E, Rosa I, Parguiña AF, Motahedeh S, Varon D, García Á. Comparative analysis of platelet-derived microparticles reveals differences in their amount and proteome depending on the platelet stimulus. J Proteomics (2012) 76:287-96. doi:10.1016/j.jprot.2012.02.030

69. Perez-Pujol S, Marker PH, Key NS. Platelet microparticles are heterogeneous and highly dependent on the activation mechanism: studies using a new digital flow cytometer. Cytometry A (2007) 71(1):38-45. doi:10.1002/ cyto.a.20354

70. Castaman G, Yu-Feng L, Rodeghiero F. A bleeding disorder characterised by isolated deficiency of platelet microvesicle generation. Lancet (1996) 347(9002):700-1. doi:10.1016/S0140-6736(96)91259-3

71. Mattheij NJ, Braun A, van Kruchten R, Castoldi E, Pircher J, Baaten CC, et al. Survival protein anoctamin-6 controls multiple platelet responses including phospholipid scrambling, swelling, and protein cleavage. FASEB $J$ (2016) 30(2):727-37. doi:10.1096/fj.15-280446

72. Sims PJ, Wiedmer T, Esmon CT, Weiss HJ, Shattil SJ. Assembly of the platelet prothrombinase complex is linked to vesiculation of the platelet plasma membrane. Studies in Scott syndrome: an isolated defect in platelet procoagulant activity. J Biol Chem (1989) 264(29):17049-57.

73. Owens AP, Mackman N. Microparticles in hemostasis and thrombosis. Circ Res (2011) 108(10):1284-97. doi:10.1161/CIRCRESAHA.110.233056

74. Khan MM, Hattori T, Niewiarowski S, Edmunds LH Jr, Colman RW. Truncated and microparticle-free soluble tissue factor bound to peripheral monocytes preferentially activate factor VII. Thromb Haemost (2006) 95(3):462-8. doi:10.1160/TH05-06-0432

75. Dahlback B, Wiedmer T, Sims PJ. Binding of anticoagulant vitamin K-dependent protein $\mathrm{S}$ to platelet-derived microparticles. Biochemistry (1992) 31(51):12769-77. doi:10.1021/bi00166a009

76. Somajo S, Koshiar RL, Norström E, Dahlbäck B. Protein S and factor V in regulation of coagulation on platelet microparticles by activated protein $\mathrm{C}$. Thromb Res (2014) 134(1):144-52. doi:10.1016/j.thromres.2014.04.031

77. Stavenuiter F, Davis NF, Duan E, Gale AJ, Heeb MJ. Platelet protein S directly inhibits procoagulant activity on platelets and microparticles. Thromb Haemost (2013) 109(2):229-37. doi:10.1160/TH12-08-0622

78. Berckmans RJ, Nieuwland R, Böing AN, Romijn FP, Hack CE, Sturk A. Cell-derived microparticles circulate in healthy humans and support low grade thrombin generation. Thromb Haemost (2001) 85(4):639-46.

79. Tans G, Rosing J, Thomassen MC, Heeb MJ, Zwaal RF, Griffin JH. Comparison of anticoagulant and procoagulant activities of stimulated platelets and platelet-derived microparticles. Blood (1991) 77(12):2641-8.

80. Cloutier N, Tan S, Boudreau LH, Cramb C, Subbaiah R, Lahey L, et al. The exposure of autoantigens by microparticles underlies the formation of potent inflammatory components: the microparticle-associated immune complexes. EMBO Mol Med (2013) 5(2):235-49. doi:10.1002/emmm. 201201846

81. Bei JJ, Liu C, Peng S, Liu CH, Zhao WB, Qu XL, et al. Staphylococcal SSL5-induced platelet microparticles provoke proinflammatory responses 
via the CD40/TRAF6/NFkappaB signalling pathway in monocytes. Thromb Haemost (2016) 115(3):632-45. doi:10.1160/TH15-04-0322

82. Forlow SB, McEver RP, Nollert MU. Leukocyte-leukocyte interactions mediated by platelet microparticles under flow. Blood (2000) 95(4): 1317-23.

83. Dinkla S, van Cranenbroek B, van der Heijden WA, He X, Wallbrecher R, Dumitriu IE, et al. Platelet microparticles inhibit IL-17 production by regulatory T cells through P-selectin. Blood (2016) 127(16):1976-86. doi:10.1182/ blood-2015-04-640300

84. Sadallah S, Eken C, Martin PJ, Schifferli JA. Microparticles (ectosomes) shed by stored human platelets downregulate macrophages and modify the development of dendritic cells. J Immunol (2011) 186(11):6543-52. doi:10.4049/jimmunol.1002788

85. Tang K, Liu J, Yang Z, Zhang B, Zhang H, Huang C, et al. Microparticles mediate enzyme transfer from platelets to mast cells: a new pathway for lipoxin A4 biosynthesis. Biochem Biophys Res Commun (2010) 400(3):432-6. doi:10.1016/j.bbrc.2010.08.095

86. Baker N, O’Meara SJ, Scannell M, Maderna P, Godson C. Lipoxin A4: antiinflammatory and anti-angiogenic impact on endothelial cells. J Immunol (2009) 182(6):3819-26. doi:10.4049/jimmunol.0803175

87. Braig D, Nero TL, Koch HG, Kaiser B, Wang X, Thiele JR, et al. Transitional changes in the CRP structure lead to the exposure of proinflammatory binding sites. Nat Commun (2017) 8:14188. doi:10.1038/ ncomms 14188

88. Habersberger J, Strang F, Scheichl A, Htun N, Bassler N, Merivirta RM, et al. Circulating microparticles generate and transport monomeric C-reactive protein in patients with myocardial infarction. Cardiovasc Res (2012) 96(1):64-72. doi:10.1093/cvr/cvs237

89. Thiele JR, Habersberger J, Braig D, Schmidt Y, Goerendt K, Maurer V, et al. Dissociation of pentameric to monomeric C-reactive protein localizes and aggravates inflammation: in vivo proof of a powerful proinflammatory mechanism and a new anti-inflammatory strategy. Circulation (2014) 130(1):35-50. doi:10.1161/CIRCULATIONAHA.113.007124

90. Eisenhardt SU, Thiele JR, Bannasch H, Stark GB, Peter K. C-reactive protein: how conformational changes influence inflammatory properties. Cell Cycle (2009) 8(23):3885-92. doi:10.4161/cc.8.23.10068

91. Eisenhardt SU, Habersberger J, Murphy A, Chen YC, Woollard KJ, Bassler N, et al. Dissociation of pentameric to monomeric C-reactive protein on activated platelets localizes inflammation to atherosclerotic plaques. Circ Res (2009) 105(2):128-37. doi:10.1161/CIRCRESAHA.108. 190611

92. Martin KR, Kantari-Mimoun C, Yin M, Pederzoli-Ribeil M, AngelotDelettre F, Ceroi A, et al. Proteinase 3 is a phosphatidylserine-binding protein that affects the production and function of microvesicles. J Biol Chem (2016) 291(20):10476-89. doi:10.1074/jbc.M115.698639

93. Kim HK, Song KS, Chung JH, Lee KR, Lee SN. Platelet microparticles induce angiogenesis in vitro. Br J Haematol (2004) 124(3):376-84. doi:10.1046/j.1365-2141.2003.04773.x

94. Sun C, Feng SB, Cao ZW, Bei JJ, Chen Q, Zhao WB, et al. Up-regulated expression of matrix metalloproteinases in endothelial cells mediates platelet microvesicle-induced angiogenesis. Cell Physiol Biochem (2017) 41(6):2319-32. doi:10.1159/000475651

95. Brill A, Dashevsky O, Rivo J, Gozal Y, Varon D. Platelet-derived microparticles induce angiogenesis and stimulate post-ischemic revascularization. Cardiovasc Res (2005) 67(1):30-8. doi:10.1016/j.cardiores.2005. 04.007

96. Mause SF, Ritzel E, Liehn EA, Hristov M, Bidzhekov K, Müller-Newen G, et al. Platelet microparticles enhance the vasoregenerative potential of angiogenic early outgrowth cells after vascular injury. Circulation (2010) 122(5):495-506. doi:10.1161/CIRCULATIONAHA.109.909473

97. Hayon Y, Dashevsky O, Shai E, Varon D, Leker RR. Platelet microparticles promote neural stem cell proliferation, survival and differentiation. J Mol Neurosci (2012) 47(3):659-65. doi:10.1007/s12031-012-9711-y

98. Janowska-Wieczorek A, Wysoczynski M, Kijowski J, Marquez-Curtis L, Machalinski B, Ratajczak J, et al. Microvesicles derived from activated platelets induce metastasis and angiogenesis in lung cancer. Int J Cancer (2005) 113(5):752-60. doi:10.1002/ijc.20657

99. Wang H, Wang ZH, Kong J, Yang MY, Jiang GH, Wang XP, et al. Oxidized low-density lipoprotein-dependent platelet-derived microvesicles trigger procoagulant effects and amplify oxidative stress. Mol Med (2012) 18:159-66. doi:10.2119/molmed.2011.00295

100. Libby P, Ridker PM, Hansson GK. Progress and challenges in translating the biology of atherosclerosis. Nature (2011) 473(7347):317-25. doi:10.1038/ nature10146

101. Marcos-Ramiro B, Oliva Nacarino P, Serrano-Pertierra E, Blanco-Gelaz MA, Weksler BB, Romero IA, et al. Microparticles in multiple sclerosis and clinically isolated syndrome: effect on endothelial barrier function. $B M C$ Neurosci (2014) 15:110. doi:10.1186/1471-2202-15-110

102. Mause SF, von Hundelshausen P, Zernecke A, Koenen RR, Weber C. Platelet microparticles: a transcellular delivery system for RANTES promoting monocyte recruitment on endothelium. Arterioscler Thromb Vasc Biol (2005) 25(7):1512-8. doi:10.1161/01.ATV.0000170133.43608.37

103. Nomura S, Tandon NN, Nakamura T, Cone J, Fukuhara S, Kambayashi J. High-shear-stress-induced activation of platelets and microparticles enhances expression of cell adhesion molecules in THP-1 and endothelial cells. Atherosclerosis (2001) 158(2):277-87. doi:10.1016/S0021-9150(01) 00433-6

104. Vasina EM, Cauwenberghs S, Staudt M, Feijge MA, Weber C, Koenen RR, et al. Aging- and activation-induced platelet microparticles suppress apoptosis in monocytic cells and differentially signal to proinflammatory mediator release. Am J Blood Res (2013) 3(2):107-23.

105. Böing AN, Hau CM, Sturk A, Nieuwland R. Platelet microparticles contain active caspase 3. Platelets (2008) 19(2):96-103. doi:10.1080/ 09537100701777295

106. Pakala R. Serotonin and thromboxane A2 stimulate platelet-derived microparticle-induced smooth muscle cell proliferation. Cardiovasc Radiat Med (2004) 5(1):20-6. doi:10.1016/j.carrad.2003.12.002

107. Weber A, Koppen HO, Schror K. Platelet-derived microparticles stimulate coronary artery smooth muscle cell mitogenesis by a PDGFindependent mechanism. Thromb Res (2000) 98(5):461-6. doi:10.1016/ S0049-3848(00)00192-4

108. Leroyer AS, Isobe H, Lesèche G, Castier $\mathrm{Y}$, Wassef M, Mallat Z, et al. Cellular origins and thrombogenic activity of microparticles isolated from human atherosclerotic plaques. J Am Coll Cardiol (2007) 49(7):772-7. doi:10.1016/j.jacc.2006.10.053

109. Badlou BA, Wu YP, Smid WM, Akkerman JW. Platelet binding and phagocytosis by macrophages. Transfusion (2006) 46(8):1432-43. doi:10.1111/ j.1537-2995.2006.00913.x

110. Michelsen AE, Brodin E, Brosstad F, Hansen JB. Increased level of platelet microparticles in survivors of myocardial infarction. Scand J Clin Lab Invest (2008) 68(5):386-92. doi:10.1080/00365510701794957

111. Porto I, Biasucci LM, De Maria GL, Leone AM, Niccoli G, Burzotta F, et al. Intracoronary microparticles and microvascular obstruction in patients with ST elevation myocardial infarction undergoing primary percutaneous intervention. Eur Heart J (2012) 33(23):2928-38. doi:10.1093/ eurheartj/ehs065

112. Jung C, Sörensson P, Saleh N, Arheden H, Rydén L, Pernow J. Circulating endothelial and platelet derived microparticles reflect the size of myocardium at risk in patients with ST-elevation myocardial infarction. Atherosclerosis (2012) 221(1):226-31. doi:10.1016/j.atherosclerosis.2011.12.025

113. Montoro-García S, Shantsila E, Tapp LD, López-Cuenca A, Romero AI, Hernández-Romero $\mathrm{D}$, et al. Small-size circulating microparticles in acute coronary syndromes: relevance to fibrinolytic status, reparative markers and outcomes. Atherosclerosis (2013) 227(2):313-22. doi:10.1016/j. atherosclerosis.2013.01.028

114. Giannopoulos G, Oudatzis G, Paterakis G, Synetos A, Tampaki E, Bouras G, et al. Red blood cell and platelet microparticles in myocardial infarction patients treated with primary angioplasty. Int J Cardiol (2014) 176(1):145-50. doi:10.1016/j.ijcard.2014.07.022

115. Tan KT, Tayebjee MH, Macfadyen RJ, Lip GY, Blann AD. Elevated platelet microparticles in stable coronary artery disease are unrelated to disease severity or to indices of inflammation. Platelets (2005) 16(6):368-71. doi:10.1080/00207230500120401

116. Galli M, Grassi A, Barbui T. Platelet-derived microvesicles in thrombotic thrombocytopenic purpura and hemolytic uremic syndrome. Thromb Haemost (1996) 75(3):427-31.

117. Sewify EM, Sayed D, Abdel Aal RF, Ahmad HM, Abdou MA. Increased circulating red cell microparticles (RMP) and platelet microparticles (PMP) 
in immune thrombocytopenic purpura. Thromb Res (2013) 131(2):e59-63. doi:10.1016/j.thromres.2012.11.021

118. Bal L, Ederhy S, Di Angelantonio E, Toti F, Zobairi F, Dufaitre G, et al. Circulating procoagulant microparticles in acute pulmonary embolism: a case-control study. Int J Cardiol (2010) 145(2):321-2. doi:10.1016/j. ijcard.2009.11.048

119. Bucciarelli P, Martinelli I, Artoni A, Passamonti SM, Previtali E, Merati G, et al. Circulating microparticles and risk of venous thromboembolism. Thromb Res (2012) 129(5):591-7. doi:10.1016/j.thromres.2011.08.020

120. Campello E, Spiezia L, Radu CM, Bulato C, Castelli M, Gavasso S, et al. Endothelial, platelet, and tissue factor-bearing microparticles in cancer patients with and without venous thromboembolism. Thromb Res (2011) 127(5):473-7. doi:10.1016/j.thromres.2011.01.002

121. Ramacciotti E, Blackburn S, Hawley AE, Vandy F, Ballard-Lipka N, Stabler C, et al. Evaluation of soluble P-selectin as a marker for the diagnosis of deep venous thrombosis. Clin Appl Thromb Hemost (2011) 17(4):425-31. doi:10.1177/1076029611405032

122. Campello E, Spiezia L, Radu CM, Bulato C, Gavasso S, Tormene D, et al. Circulating microparticles and the risk of thrombosis in inherited deficiencies of antithrombin, protein C and protein S. Thromb Haemost (2016) 115(1):81-8. doi:10.1160/TH15-04-0286

123. Lincz LF, Scorgie FE, Enjeti A, Seldon M. Variable plasma levels of factor V Leiden correlate with circulating platelet microparticles in carriers of factor V Leiden. Thromb Res (2012) 129(2):192-6. doi:10.1016/j.thromres.2011. 06.018

124. Ye R, Ye C, Huang Y, Liu L, Wang S. Circulating tissue factor positive microparticles in patients with acute recurrent deep venous thrombosis. Thromb Res (2012) 130(2):253-8. doi:10.1016/j.thromres.2011.10.014

125. Chirinos JA, Heresi GA, Velasquez H, Jy W, Jimenez JJ, Ahn E, et al. Elevation of endothelial microparticles, platelets, and leukocyte activation in patients with venous thromboembolism. JAm Coll Cardiol (2005) 45(9):1467-71. doi:10.1016/j.jacc.2004.12.075

126. Martinez M, Ricart JM, Ruiz-Aja S, Rus A, Todolí J, Calvo J, et al. Platelet activation and red blood cell phosphatidylserine exposure evaluated by flow cytometry in patients with Behcet's disease: are they related to thrombotic events? Pathophysiol Haemost Thromb (2007) 36(1):18-22. doi:10.1159/000112635

127. Yuana Y, Bertina RM, Osanto S. Pre-analytical and analytical issues in the analysis of blood microparticles. Thromb Haemost (2011) 105(3):396-408. doi:10.1160/TH10-09-0595

128. Kong F, Zhang L, Wang H, Yuan G, Guo A, Li Q, et al. Impact of collection, isolation and storage methodology of circulating microvesicles on flow cytometric analysis. Exp Ther Med (2015) 10(6):2093-101. doi:10.3892/ etm.2015.2780

129. Trummer A, De Rop C, Tiede A, Ganser A, Eisert R. Recovery and composition of microparticles after snap-freezing depends on thawing temperature. Blood Coagul Fibrinolysis (2009) 20(1):52-6. doi:10.1097/ MBC.0b013e32831be9c5

130. Chandler WL. Microparticle counts in platelet-rich and platelet-free plasma, effect of centrifugation and sample-processing protocols. Blood Coagul Fibrinolysis (2013) 24(2):125-32. doi:10.1097/MBC.0b013e32835a0824

131. Jayachandran M, Miller VM, Heit JA, Owen WG. Methodology for isolation, identification and characterization of microvesicles in peripheral blood. JImmunol Methods (2012) 375(1-2):207-14. doi:10.1016/j. jim.2011.10.012

132. Pospichalova V, Svoboda J, Dave Z, Kotrbova A, Kaiser K, Klemova D, et al. Simplified protocol for flow cytometry analysis of fluorescently labeled exosomes and microvesicles using dedicated flow cytometer. J Extracell Vesicles (2015) 4:25530. doi:10.3402/jev.v4.25530

133. Li P, Kaslan M, Lee SH, Yao J, Gao Z. Progress in exosome isolation techniques. Theranostics (2017) 7(3):789-804. doi:10.7150/thno.18133

134. Lobb RJ, Becker M, Wen SW, Wong CS, Wiegmans AP, Leimgruber A, et al. Optimized exosome isolation protocol for cell culture supernatant and human plasma. JExtracell Vesicles (2015) 4:27031. doi:10.3402/jev. v4.27031

135. Gardiner C, Di Vizio D, Sahoo S, Théry C, Witwer KW, Wauben M, et al. Techniques used for the isolation and characterization of extracellular vesicles: results of a worldwide survey. J Extracell Vesicles (2016) 5:32945. doi:10.3402/jev.v5.32945
136. Poncelet P, Robert S, Bailly N, Garnache-Ottou F, Bouriche T, Devalet B, et al. Tips and tricks for flow cytometry-based analysis and counting of microparticles. Transfus Apher Sci (2015) 53(2):110-26. doi:10.1016/j. transci.2015.10.008

137. Headland SE, Jones HR, D'Sa AS, Perretti M, Norling LV. Cuttingedge analysis of extracellular microparticles using ImageStream(X) imaging flow cytometry. Sci Rep (2014) 4:5237. doi:10.1038/srep05237

138. Chandler WL. Measurement of microvesicle levels in human blood using flow cytometry. Cytometry B Clin Cytom (2016) 90(4):326-36. doi:10.1002/ cyto.b. 21343

139. EV-TRACK Consortium, Van Deun J, Mestdagh P, Agostinis P, Akay Ö, Anand S, et al. EV-TRACK: transparent reporting and centralizing knowledge in extracellular vesicle research. Nat Methods (2017) 14(3):228-32. doi:10.1038/nmeth.4185

140. Witwer KW, Buzás EI, Bemis LT, Bora A, Lässer C, Lötvall J, et al. Standardization of sample collection, isolation and analysis methods in extracellular vesicle research. J Extracell Vesicles (2013) 27:2. doi:10.3402/jev. v2i0.20360

141. Lötvall J, Hill AF, Hochberg F, Buzás EI, Di Vizio D, Gardiner C, et al. Minimal experimental requirements for definition of extracellular vesicles and their functions: a position statement from the International Society for Extracellular Vesicles. J Extracell Vesicles (2014) 3:26913. doi:10.3402/ jev.v3.26913

142. Lener T, Gimona M, Aigner L, Börger V, Buzas E, Camussi G, et al. Applying extracellular vesicles based therapeutics in clinical trials - an ISEV position paper. J Extracell Vesicles (2015) 4:30087. doi:10.3402/jev. $\mathrm{v} 4.30087$

143. Giacomazzi A, Degan M, Calabria S, Meneguzzi A, Minuz P. Antiplatelet agents inhibit the generation of platelet-derived microparticles. Front Pharmacol (2016) 7:314. doi:10.3389/fphar.2016.00314

144. Connor DE, Ly K, Aslam A, Boland J, Low J, Jarvis S, et al. Effects of antiplatelet therapy on platelet extracellular vesicle release and procoagulant activity in health and in cardiovascular disease. Platelets (2016) 27(8):805-11. doi:10.1080/09537104.2016.1190008

145. Bulut D, Becker V, Mugge A. Acetylsalicylate reduces endothelial and platelet-derived microparticles in patients with coronary artery disease. Can J Physiol Pharmacol (2011) 89(4):239-44. doi:10.1139/y11-013

146. Skeppholm M, Mobarrez F, Malmqvist K, Wallén H. Platelet-derived microparticles during and after acute coronary syndrome. Thromb Haemost (2012) 107(6):1122-9. doi:10.1160/TH11-11-0779

147. Pawlowski CL, Li W, Sun M, Ravichandran K, Hickman D, Kos C, et al. Platelet microparticle-inspired clot-responsive nanomedicine for targeted fibrinolysis. Biomaterials (2017) 128:94-108. doi:10.1016/j.biomaterials. 2017.03.012

148. Ohtsuka M, Sasaki K, Ueno T, Seki R, Nakayoshi T, Koiwaya H, et al. Platelet-derived microparticles augment the adhesion and neovascularization capacities of circulating angiogenic cells obtained from atherosclerotic patients. Atherosclerosis (2013) 227(2):275-82. doi:10.1016/j. atherosclerosis.2013.01.040

149. Ma F, Liu H, Shen Y, Zhang Y, Pan S. Platelet-derived microvesicles are involved in cardio-protective effects of remote preconditioning. Int J Clin Exp Pathol (2015) 8(9):10832-9.

150. Shan LY, Li JZ, Zu LY, Niu CG, Ferro A, Zhang YD, et al. Plateletderived microparticles are implicated in remote ischemia conditioning in a rat model of cerebral infarction. CNS Neurosci Ther (2013) 19(12):917-25. doi:10.1111/cns. 12199

151. Kervadec A, Bellamy V, El Harane N, Arakélian L, Vanneaux V, Cacciapuoti I, et al. Cardiovascular progenitor-derived extracellular vesicles recapitulate the beneficial effects of their parent cells in the treatment of chronic heart failure. J Heart Lung Transplant (2016) 35(6):795-807. doi:10.1016/j. healun.2016.01.013

152. Sun D, Zhuang X, Xiang X, Liu Y, Zhang S, Liu C, et al. A novel nanoparticle drug delivery system: the anti-inflammatory activity of curcumin is enhanced when encapsulated in exosomes. Mol Ther (2010) 18(9):1606-14. doi:10.1038/mt.2010.105

153. Zhuang X, Xiang X, Grizzle W, Sun D, Zhang S, Axtell RC, et al. Treatment of brain inflammatory diseases by delivering exosome encapsulated anti-inflammatory drugs from the nasal region to the brain. Mol Ther (2011) 19(10):1769-79. doi:10.1038/mt.2011.164 
154. Tian Y, Li S, Song J, Ji T, Zhu M, Anderson GJ, et al. A doxorubicin delivery platform using engineered natural membrane vesicle exosomes for targeted tumor therapy. Biomaterials (2014) 35(7):2383-90. doi:10.1016/j. biomaterials.2013.11.083

155. Gould SJ, Raposo G. As we wait: coping with an imperfect nomenclature for extracellular vesicles. J Extracell Vesicles (2013) 2(1):20389. doi:10.3402/ jev.v2i0.20389

156. Alvarez-Erviti L, Seow Y, Yin H, Betts C, Lakhal S, Wood MJ. Delivery of siRNA to the mouse brain by systemic injection of targeted exosomes. Nat Biotechnol (2011) 29(4):341-5. doi:10.1038/nbt.1807
Conflict of Interest Statement: The authors declare that the research was conducted in the absence of any commercial or financial relationships that could be construed as a potential conflict of interest.

Copyright (C) 2017 Zaldivia, McFadyen, Lim, Wang and Peter. This is an open-access article distributed under the terms of the Creative Commons Attribution License (CC BY). The use, distribution or reproduction in other forums is permitted, provided the original author(s) or licensor are credited and that the original publication in this journal is cited, in accordance with accepted academic practice. No use, distribution or reproduction is permitted which does not comply with these terms. 